\title{
Government communication and Internet responses: profile of Prime Minister Krišjānis Karin̄š in selected digital media users' comments during the COVID-19 pandemic
}

\author{
Vineta Kleinberga \\ Faculty of European Studies \\ Rīga Stradiñ̌ University \\ Riga, Latvia \\ vineta.kleinberga@rsu.lv
}

\begin{abstract}
Perceptions play a pivotal role in assessment of efficiency of government communication. Informed by the strategic narrative conceptual framework this study looks at perception of government communication in Internet comments during three essential dates in conquering the COVID-19 pandemic in Latvia: introduction of emergency situations on March 12 and November 6, 2020, and introduction of a curfew on December 29, 2020. The study uncovers how often and how the main spokesperson in government communication - the Prime Minister of Latvia Krišjānis Karin̄š - is framed in comments of three online news media in Latvia (Apollo, Delfi, Tvnet) in Latvian and Russian. Using a digital tool for online comments analysis the Index of Internet Aggressiveness (IIA), a data set is created of 244 comments, containing a key word "Kariņš" in various cases in Latvian and Russian. Qualitative content analysis is applied to extract and to compare the frequency of appearance and the framing of Kariňš over the course of the pandemic in Latvia. The findings reveal that Kariňš appears in comments significantly more after news in Latvian than in Russian, and has been commented five times more in Delfi than in Tvnet and Apollo together. The comments in Latvian are more aggressive than in Russian, and their emotional tone increases towards the end of 2020. In majority of comments the framing is negative involving attributes of irresponsibility, superficiality, indecisiveness and danger; yet positively framed rigidity and decisiveness of Kariňš can be observed too.

IIA is an online comment analysis tool, incorporating a machine learning program, which analyses users' comments on news on online news sites according to pre-selected keywords to grasp the commenters' verbal aggressiveness. In March 2021 the IIA data set consists of $\sim 25.08$ million comments; 616.62 million word usage in written commenting and $\sim 1357.40$ thousand news.
\end{abstract}

Keywords - COVID-19, audience perception, internet comments, Kariṇš, Latvia

\section{INTRODUCTION}

COVID-19 pandemic has brought to attention the importance of information and its perception, as people's behavior is directly influenced by their trust to the information sources [1], [2], [3]. During the pandemic government institutions have been among the most important ones, providing information on the virus and its containment. However, studies on the government strategic narratives have shown that not only provision of information but also its reception pays a pivotal role in efficiency of government communication [4].

This study is based on a premise that user comments after the online news articles form a useful source for exploring the inhabitants' perceptions on the government communication. Nowadays commenting is the most commonly used form for online participation; and with it the commenters not only demonstrate their own opinion, but also influence the opinions of others [5]. Therefore, in addition to traditional methods of exploring public perceptions such as surveys, focus groups and interviews, analysis of Internet comments adds an important dimension to understanding the public mood. It has been argued that anonymity of social interaction reduces the determination of individuals to adhere to certain social norms [6], liberating the individuals from the need "to behave in certain ways" as they are free to be "whoever they want to be - only to simply - $\log$ off at the end of the day" [7, p. 6]. Thus, for researchers, Internet comments open up possibilities to explore sentiments, which people would avoid in public environment.

Online ISSN 2256-070X

https://doi.org/10.17770/etr2021vol2.6571

(C) 2021 Vineta Kleinberga. Published by Rezekne Academy of Technologies. This is an open access article under the Creative Commons Attribution 4.0 International License. 
This study explores the perception on Latvia's Prime Minister Krišjānis Kariņš (hereinafter - Kariņ̌s) by users of three online news media in Latvia (Delfi, Tvnet, Apollo) at three essential dates in conquering the COVID-19 pandemic in Latvia: introduction of emergency situations on March 12 and November 6, 2020, and introduction of a curfew on December 29, 2020. These dates were selected because introduction of an emergency situation and a curfew is not a business-as-usual situation in policy making. Neither politicians, nor inhabitants were experienced in living in emergency conditions, consisting of numerous restrictions and rules. Hypothesizing that unexpected situations intensify emotions and these emotions are targeted against the main perpetrators of obnoxious decisions, this study asks the following research questions:

1) Are the user comments of online news stories targeted towards Kariņs, the main spokesperson of the government communication in Latvia?

2) How is Kariņš framed in the comments?

To answer the questions, the study uses an automated tool for analysis of verbal aggressiveness in Internet comments - the Index of Internet Aggressiveness (IIA). Applying the IIA, a number of comments, a level of aggressiveness and all Kariňš related comments both in Latvian and Russian languages in the three dates of the pandemic are determined. The findings are complemented by qualitative content analysis to extract the framing of Kariņš in the selected Internet comments. The data illuminate the opportunities, provided by IIA, for audience perception studies.

\section{METHODS}

This study combines two research methods: for selection and analysis of comments an automated tool for online comments analysis - the IIA (http://barometrs.korpuss.lv) is applied, whereas for analysis of framing a manual content analysis is used. The IIA has been elaborated by Rīga Stradiņš University and the Institute of Mathematics and Computer Science of the University of Latvia for measuring the level of aggressiveness, trends and causes in the user comments of three news portals (Delfi, Tvnet, Apollo) with the largest audiences [8] in Latvia. The IIA can assess the level of aggression in user comments in Latvian and Russian in a given time period and dates, the most frequently used keywords in response to news content, and the relationship between news and comments. The IIA incorporates a machine learning program, which analyses user comments on online news stories according to pre-selected keywords to grasp the commenters' verbal aggressiveness [9, p. 168]. It has been estimated that the accuracy of the automatic classifier was $72.2 \%$, having a close resemblance to the inter-annotator agreement of $78 \%$ [10]. In 2020, the IIA was updated to incorporate keywords characterising commenters' aggressiveness towards the COVID-19 pandemic. In March 2021, the IIA data set consists of
25.08 million comments, 616.62 million word usage in written commenting and $~ 1357.40$ thousand news [11].

Applying the function of the IIA "Common trends" (Kopejjās tendences, in Latvian) it was determined what was the average level of aggressiveness in the observed dates and whether the comments, containing the keyword "Karinss", referred to the TOP 10 of the most aggressively commented articles of a particular date. After that a share of Kariņš related comments in the comments of aggressively commented articles was identified.

The function "Contexts” (Konteksti, in Latvian) allows to identify the objects that cause verbal aggression. For the purposes of this study, the function "Contexts" was used to identify how much and what type of aggression was facilitated by Karinšs. Overall, 263 comments from Apollo, Delfi and Tvnet in Latvian and Russian languages have been selected. All of them contained a keyword "Kariņš" in various cases in Latvian ("Karinsš", "Karina", "Karinam", "Karinuu”, "Karin̄ā", "Karin’”) and Russian (“Кариньш”, “Кариньша”, “Кариньшу”, “Кариньше”). The use of diacritic marks in Latvian and of Latin letters instead of Cyrillic in Russian comments did not have an impact on the sample. The data-set has been reduced up to 244 comments, excluding the comments, where "Kariņš", was not used as a proper noun. Comments that contained a keyword in various cases and comments that were repeated in exactly the same form after several articles have been analysed once.

In addition to the automated IIA-driven analysis, qualitative content analysis has been applied to extract and to compare the framing of Karinšs in the selected sample of comments over the course of the pandemic in Latvia. Framing refers to "selecting and highlighting some facets of events or issues, and making connections among them so as to promote a particular interpretation, evaluation, and/or solution” [12, p. 417]. Analysis of framing provides an insight into the emotional variations of comments, which altogether are categorized as aggressive. Framing of Kariňš was analysed following a codebook consisting of 9 code groups. Comments, related to news stories about COVID-19, were separated from other comments. 20 categories, revealing particular human characteristics, both positive and negative, were invented. The categories are derived from the six basic emotions - happiness, sadness, anger, fear, disgust, and surprise, as classified by discrete emotion theorists [13]. Except the latter, these emotions are considered to be relevant for this study, and are expanded to diversify the emotional framing. As a result, anger is manifested in comments that frame Karinš as irresponsible, superficial, detached/unreliable, unfair and guilty. Disgust is revealed in comments that frame Karinš as a stooge or as being omniscient, arrogant/annoying, meaningless/dumb, incompetent, crafty and hypocritical. Sadness is expressed in comments that frame Kariňs as weak/indecisive, uninformed/ naïve and confused. Fear appears in comments which frame Kariņš as dangerous and authoritarian. Happiness is manifested in comments framing Kariņ̌s as responsible, decisive and having done maximum possible 
Environment. Technology. Resources. Rezekne, Latvia Proceedings of the $13^{\text {th }}$ International Scientific and Practical Conference. Volume 2, 78-83

in a positive sense. Comments without a particular emotional framing are included in the category "neutral".

\section{RESULTS AND DISCUSSION}

This study demonstrates that Karinšs has been commented five times more in Delfi than in Tvnet and Apollo together (Table 1). He has been mentioned in comments more, when the first emergency situation on March 12, 2020, was introduced. The amount of comments decreases and is almost the same at the moment of announcement of the second state of emergency on November 6 and introduction of a curfew on December 29, 2020.

TABLE 1. FREQUENCY OF KARIN̦Š RELATED COMMENTS ACROSS DATES AND NEWS PORTALS

\begin{tabular}{|l|c|c|c|c|}
\hline & $\mathbf{1 2 . 0 3 .}$ & $\mathbf{0 6 . 1 1}$ & $\mathbf{2 9 . 1 2 .}$ & $\begin{array}{c}\text { Number of } \\
\text { comments }\end{array}$ \\
\hline Apollo & 2 & 0 & 10 & 12 \\
\hline Delfi & 85 & 73 & 44 & 202 \\
\hline Tvnet & 8 & 0 & 22 & 30 \\
\hline Total & 95 & 73 & 76 & 244 \\
\hline
\end{tabular}

Kariņš appears in comments significantly more after news in Latvian than in Russian (Table 2). In the Latvian versions of Apollo, Delfi and Tvnet there are 211 comments, yet the Russian versions of the same news portals have only 33 comments. Arguably, it resonates with the finding that for the Russian-speaking journalists it was more difficult to gain an up-to-date information from the Latvian government in Russian [9, pp. pp. 46-48], which resulted in less news on COVID-19 in the Russianspeaking portals.

TABLE 2. FREQUENCY OF COMMENTS ACROSS LATVIAN AND RUSSIAN NEWS PORTALS

\begin{tabular}{|l|c|c|c|c|c|c|}
\hline \multirow{2}{*}{} & \multicolumn{2}{|c|}{ 12.03. } & \multicolumn{2}{c|}{ 06.11. } & \multicolumn{2}{c|}{ 29.12. } \\
\cline { 2 - 7 } & $\boldsymbol{L V}$ & $\boldsymbol{R U}$ & $\boldsymbol{L V}$ & $\boldsymbol{R U}$ & $\boldsymbol{L V}$ & $\boldsymbol{R U}$ \\
\hline Apollo & 2 & 0 & 0 & 0 & 10 & 0 \\
\hline Delfi & 78 & 7 & 69 & 4 & 25 & 19 \\
\hline Tvnet & 7 & 1 & 0 & 0 & 20 & 2 \\
\hline Total & 87 & 8 & 69 & 4 & 55 & 21 \\
\hline
\end{tabular}

Delfi is the most popular news portal both among the Latvian and the Russian audiences, collecting 172 comments in Latvian and 30 comments in Russian. The data uncover a decreasing trend of Kariņš related comments towards the end of 2020 in Latvian. Whereas on March 12 Karinšs appeared in 87 comments, on December 29 he was mentioned in 55 comments. In Russian, a sharply increasing trend at the very end of 2020 can be observed. Namely, Karinš appears in 8 and 4 comments on March 12 and November 6 respectively, and in 21 comments on December 29.
The observed trend resembles a reverse situation if compared to the general level of aggressiveness in comments (Table 3). In comments of the news in Latvian the average level of aggressiveness increases towards the end of 2020, yet in the comments, reacting to news in Russian, it decreases. So, in Latvian comments, Kariņš is mentioned less when the level of aggressiveness is high, but in Russian it is the opposite - he appears in comments more, when the overall aggression is lower.

TABLE 3. LEVEL OF AGGRESSIVENESS IN LATVIAN AND RUSSIAN NEWS PORTALS ACROSS DATES

\begin{tabular}{|l|c|c|c|}
\hline & $\mathbf{1 2 . 0 3 .}$ & $\mathbf{0 6 . 1 1 .}$ & $\mathbf{2 9 . 1 2 .}$ \\
\hline LV & 3.17 & 3.37 & 3.54 \\
\hline RU & 1.97 & 1.63 & 1.61 \\
\hline
\end{tabular}

As regards the thematic framework, majority of Kariņ related comments follow the news about the COVID-19 pandemic. Out of 244 comments, 226 react to the COVID19 news and only 18 comment other news (Table 4).

TABLE 4. THEMATIC FRAMEWORK OF COMMENTS’ RELATED NEWS

\begin{tabular}{|l|c|c|c|c|}
\hline & Apollo & Delfi & Tvnet & Total \\
\hline COVID-19 news & 12 & 184 & 28 & 226 \\
\hline Other news & 0 & 16 & 2 & 18 \\
\hline
\end{tabular}

It suggests that in audience perception in the observed dates Kariňš is primarily associated with tackling the COVID-19 crisis, not other issues.

Content-wise, the news receiving five or more Kariņs related comments refer to the following topics. On March 12 , it is the news about calling an emergency meeting of the government and the Crisis Management Council (29 comments), declaring an emergency situation (24 comments), introduction of essential safety measures, including the closure of borders (6 comments) and address of Kariňs to the parliament (5 comments). On November 6 , the news depict re-launching of an emergency situation (27 comments), impact of COVID-19 on economy (9 comments), political parties' suggestions on restraining the COVID-19 (8 comments) and COVID-19 infection and death rates in Latvia (7 comments). On December 29, majority of comments are directed towards the news on introduction of the curfew (40 comments) and involvement of police and army in control of the curfew (10 comments).

The above-mentioned news is partly represented in the articles that are the most aggressively commented ones of a particular day (Table 5). For instance, on March 12, the TOP 10 of the aggressively commented articles in Latvian contains six articles, after which comments on Kariņš are made. A share is lower in the TOP 10 in Russian. For instance, on March 12 the top of the most aggressively commented articles contains only one article with Kariņš related comments. 
Vineta Kleinberga. Government communication and Internet responses: profile of Prime Minister Krišjānis Kariņš in selected digital media users' comments during the COVID-19 pandemic

TABLE 5. SHARE OF ARTICLES WITH KARINŠ RELATED COMMENTS IN THE TOP 10 OF THE MOST AGGRESSIVELY COMMENTED ARTICLES

\begin{tabular}{|l|c|c|c|}
\hline & $\mathbf{1 2 . 0 3 .}$ & $\mathbf{0 6 . 1 1 .}$ & $\mathbf{2 9 . 1 2 .}$ \\
\hline LV & 6 & 5 & 5 \\
\hline RU & 1 & 3 & 3 \\
\hline
\end{tabular}

Overall, comments containing Karinšs form only a minor part of all comments that are devoted to a certain aggressively commented article (Table 6).

TABLE 6. SHARE OF KARINŠ RELATED COMMENTS IN THE COMMENTS OF TOP 10 AGGRESSIVELY COMMENTED ARTICLES

\begin{tabular}{|c|c|c|c|c|c|c|}
\hline & \multicolumn{2}{|c|}{12.03} & \multicolumn{2}{|c|}{06.11.} & \multicolumn{2}{|c|}{29.12.} \\
\hline & Kariṇš & Total & Kariṇš & Total & Kariṇš & Total \\
\hline $\mathrm{LV}$ & 47 & 1578 & 44 & 1710 & 25 & 1610 \\
\hline$\%$ & \multicolumn{2}{|r|}{3} & \multicolumn{2}{|r|}{2.6} & \multicolumn{2}{|r|}{1.6} \\
\hline RU & 2 & 328 & 3 & 705 & 16 & 1049 \\
\hline$\%$ & \multicolumn{2}{|r|}{0.6} & \multicolumn{2}{|r|}{0.4} & \multicolumn{2}{|r|}{1.5} \\
\hline
\end{tabular}

It can be observed that the Karinš related comments form from $0.4 \%$ to $3 \%$ of all comments that are devoted to those TOP 10 aggressively commented articles, which contain the comments on Karinšs. The proportion decreases towards the end of the year in the comments in Latvian, and increases in the comments in Russian. It resonates with the trend on frequency of Karinšs related comments in Latvian and Russian news portals.

As regards framing, in majority of COVID-19 related news comments Kariņš is framed negatively (Table 7).

TABLE 7. FRAMING OF KARIN̦Š IN NEWS COMMENTS

\begin{tabular}{|l|c|}
\hline Category & $\begin{array}{c}\text { Number of } \\
\text { comments }\end{array}$ \\
\hline Irresponsible & 25 \\
\hline Weak, indecisive & 20 \\
\hline Stooge (by the US, Soros) & 20 \\
\hline Superficial & 16 \\
\hline Neutral & 15 \\
\hline Omniscient (with irony) & 15 \\
\hline Dangerous, authoritarian & 13 \\
\hline Arrogant, annoying & 12 \\
\hline Responsible & 11 \\
\hline Detached, unreliable & 10 \\
\hline Meaningless, dumb & 9 \\
\hline Incompetent & 8 \\
\hline Unfair & 7 \\
\hline Did maximum possible (positively) & 5 \\
\hline Crafty, cheater & 5 \\
\hline Uninformed, naive & \\
\hline
\end{tabular}

\begin{tabular}{|l|c|}
\hline Category & $\begin{array}{c}\text { Number of } \\
\text { comments }\end{array}$ \\
\hline Guilty & 4 \\
\hline Decisive & 4 \\
\hline Hypocritical & 3 \\
\hline Confused & 3 \\
\hline
\end{tabular}

In equal numbers he has been framed as irresponsible (25 comments), weak and indecisive (21 comments), and superficial (20 comments). Some commenters regard talking or action of Karinš as representing omniscience (15 comments). At the beginning of the pandemic these comments reveal confusion about delays in imposing restrictions or too-weak restrictions, while towards the end of the year concerns emerge about economy, state allowances and family supply due to restrictions on shopping. Such concerns pave way for comments about detachment of Karinšs from needs of people (11 comments) and his incompetence as a head of the government (9 comments).

A part of comments at all observed dates refers to Kariņš origin as the citizen of the United States (US) (20 comments). For this, in his activity (or inactivity) in conquering the COVID-19 pandemic Karinšs has been framed as guided by the US or George Soros, the American financier and philanthropist.

One commenter states: "If Karinš gets an order from the US, he will announce a state of emergency in Latvia; if not, then everyone will have to suffer or die” [14]. Links of Kariňs with the US proportionally have been more emphasized in comments in Russian than in Latvian. In Russian, Kariņš has been depicted as a stooge of Americans in 8 comments out of 32 total COVID-19 related news' comments in Russian, while in Latvian - in 12 comments out of 194 COVID-19 related news' comments in Latvian.

Towards the end of 2020, a more aggressive tone appears in the comments. In autumn, more than in spring, Kariňs has been framed as dangerous and authoritarian (15 comments), arrogant and annoying (13 comments), and unfair (8 comments). Such representation is directed towards inadequate preparations for the second stage of the pandemic, inconsistent restrictions and unclear support to the victims of the crisis in November, and especially towards introduction of a curfew and plans to involve police and army in control of the curfew in December. As one commenter expresses: "[K] ariņš conducts a coup d' état? [T]he last time in peacetime the curfew has been introduced during the coup d'état of [U]lmanis" [15]. ${ }^{1}$ Towards the end of 2020, also more anger and fatigue from the restrictions is represented in comments. One comment states: "Mr Kariňš, please be a real statesman and don't say a speech at the turn of the years!!! Please, be quiet at least

${ }^{1}$ On 15 May 1934 the then Prime Minister of Latvia Karlis Ulmanis with the help of the army conducted a coup d'état as a result of which the system of parliamentary democracy ceased to exist in Latvia. 
Environment. Technology. Resources. Rezekne, Latvia Proceedings of the $13^{\text {th }}$ International Scientific and Practical Conference. Volume 2, 78-83

in the last minute of this year!!! Please, very much. All this is ENOUGH!” [16]. It produces comments, where Kariņš is depicted as a cheater ( 5 comments), guilty for the losses (4 comments), hypocritical (3 comments) and confused (3 comments).

On the positive side, there are 23 comments that emphasize rigidity and decisiveness of Karinšs. His ability to make unpopular decisions is underlined too, especially in autumn when the government has long been hesitating to invent stricter safety measures. Reacting to the announcement of the second state of emergency one commenter writes: "It was a long time ago needed. A badge to Karinšs who does not fear making unpopular but necessary decisions” [17]. Overall, these comments affirm that Karinšs has done everything possible yet the results would depend on inhabitants' determination to stop the pandemic.

The disproportion between the positive and the negative framing of Karinšs suggests that majority of the internet users employ the commenting opportunity to express their dissatisfaction with his work. Internet anonymity might have been a powerful factor fostering such framing. At the same time, the proportion of Karinšs related comments is low in the total number of comments after the most aggressively commented articles. It implies that Karinšs provokes a relatively small share of audience interest and aggressiveness, and by and large is not an object, which would dominate the audience discussions on COVID-19 pandemic.

\section{CONCLUSIONS}

This study demonstrates the possibility to extract a perception of a particular public figure in user comments of largest Latvian online news media by combining an automated, machine-learning based tool - the IIA - and a manual content analysis. With the help of the IIA all Karinšs related comments in three dates of the COVID-19 pandemic (March 12, November 6 and December 29) were identified and analysed, including the level of aggressiveness in these dates, a share of articles with Karinšs related comments in the TOP 10 of the most aggressively commented articles and a number of Kariňs related comments in them. The data confirmed that Karinšs was commented significantly more after news in Latvian than in Russian, and has been commented five times more in Delfi than in Tvnet and Apollo together.

However, in general user comments of online news stories targeted Kariņš relatively rarely. Kariņš received a minor part $(0.4 \%$ to $3 \%)$ of all comments that were devoted to those TOP 10 aggressively commented articles of a particular day, where he was mentioned in comments. A share of such comments decreased towards the end of 2020 in the comments in Latvian and increased in the comments in Russian.

Thematically, COVID-19 pandemic was the main topic in news, after which Kariņš related comments were made. Framing analysis revealed that in audience comments
Kariņš has been framed mostly negatively, displaying such features as irresponsibility, indecisiveness, superficiality and danger. However, around $10 \%$ of comments made a positive evaluation, emphasizing decisiveness and rigidity of Kariņš. Internet anonymity might have contributed to dominance of negativity; yet such an assumption would require more detailed qualitative studies.

\section{ACKNOWLEDGEMENTS}

This study was supported by the Ministry of Education and Science, Republic of Latvia, as part of the project "Life with COVID-19: Evaluation of overcoming the coronavirus crisis in Latvia and recommendations for societal resilience in the future" [grant number VPPCOVID-2020/1-0013].

\section{REFERENCES}

[1] D. Devine, J. Gaskell, W. Jennings and G. Stoker, "Trust and the Coronavirus Pandemic: What are the Consequences of and for Trust? An Early Review of the Literature,” Political Studies Review, 11 August 2020. https://doi.org/10.1177/1478929920948684

[2] S. Dryhurst, C. R. K. J. Schneider, A. L. J. Freeman and e. al., "Risk perceptions of COVID-19 around the world'," Journal of Risk Research, vol. 23, no. 7-8, pp. 994-1006, 2020. https://doi.org/10.1080/13669877.2020.1758193

[3] M. Siegrist, L. Luchsinger and A. Bearth, "The Impact of Trust and Risk Perception on the Acceptance of Measures to Reduce COVID-19 Cases," Risk Analysis, 12 January 2021. https://doi.org/10.1111/risa.13675

[4] A. Miskimmon, B. O'Loughlin and L. Roselle, Strategic Narratives: Communication Power and the New World Order, New York, London: Routledge, 2013.

[5] C. von Sikorski, "The Effects of Reader Comments on the Perception of Personalized Scandals: Exploring the Roles of Comment Valence and Commenters' Social Status," International Journal of Communication, vol. 10, p. 44804501, 2016. https://ijoc.org/index.php/ijoc/article/view/5748

[6] R. Spears and M. Lea, "Social influence and the influence of the "social" in computer-mediated communication," in Contexts of Computer-Mediated Communication, M. Lea, Ed., London, Harvester-Wheatsheaf, 1992, pp. 30-65.

[7] A. G. Zimmerman, Online Aggression: The Influences of Anonymity, UNF Graduate Theses and Dissertations. 403., 2012. https://digitalcommons.unf.edu/etd/403

[8] Gemius Audience, “Domains,” March 2021. [Online]. Available: https://rating.gemius.com/lv/tree/64. [Accessed 15 March 2021].

[9] RSU, VA, RTA, "Izvērtējums par valsts pārvaldes iestāžu, darba devēju, nevalstisko organizāciju sniegtā informatīvā un metodiskā atbalsta efektivitāti, mērḳa grupu informēšanai atbilstošāko informācijas kanālu un veidu izvēli," [Assessment of the effectiveness of information and methodological support provided by government institutions, employers, nongovernmental organisations, and the choice of the most relevant information channels and types for informing the target groups] RSU, Riga, 2020. https://www.rsu.lv/sites/default/files/imce/Projekti/VPP COVI D/34 zinojums_final.pdf

[10] G. Garkāje, E. Zilgalve and R. Darğis, "Normalization and Automatized Sentiment. Analysis of Contemporary Online Latvian Language.," Human Language Technologies - The Baltic Perspective, vol. 268, pp. 83-86, 2014. https://ebooks.iospress.nl/publication/38008 
Vineta Kleinberga. Government communication and Internet responses: profile of Prime Minister Krišjānis Kariņš in selected digital media users' comments during the COVID-19 pandemic

[11] RSU/IMCS UL, "Interneta agresivitātes indekss: Covid-19 versija [Index of Internet Aggressiveness: Covid-19 version]," [Online]. Available: http://barometrs.korpuss.lv/?from=2020$\underline{03-18 \& \text { to }=2021-03-18 \& \text { site }=\text { lv\&section }=\text { about. }}$ [Accessed 19 March 2021]

[12] R. M. Entman, "Cascading Activation: Contesting the White House's Frame After 9/11," Political Communication, vol. 20, no. 4, pp. 415-432, 2003.

https://doi.org/10.1080/10584600390244176

[13] I.Lopatovska, I.Arapakis, "Theories, methods and current research on emotions in library and information science, information retrieval and human - computer interaction,” Information Processing \& Management, vol. 47, no. 4, pp. 575-592, 2011. https://doi.org/10.1016/j.ipm.2010.09.001

[14] Commenter 1 on, "Video: 'Šĩ slimīiba nav apturama, bet ierobežojama' - Latvijā 'Covid-19' dẹl izsludina ārkārtas situāciju (plkst. 19:33) [Video: 'This disease cannot be stopped but controlled' - Latvia introduces 'Covid-19' emergency (at 19:33)],” Delfi, 12 March 2020. [Online]. Available: https://www.delfi.lv/news/national/politics/video-si-slimibanav-apturama-bet-ierobezojama-latvija-covid-19-del-izsludinaarkartas-situaciju-plkst-1933.d?id=51958457
[15] Commenter 2 on, "Noteiktos laikos Latvijā ieviesta komandantstunda [A curfew introduced in Latvia at specified times],” TVNET, 29 December 2020. [Online]. Available: https://www.tvnet.lv/7143267/noteiktos-laikos-latvija-ieviestakomandantstunda

[16] Commenter 3 on, "Video: Cīṇa ar Covid-19 - ko lēma valdība [Video: Fight with Covid-19 - what was decided by the government],” Delfi, 29 December 2020. [Online]. Available: https://www.delfi.lv/news/national/politics/video-cina-arcovid-19-ko-lema-valdiba.d?id=52795147

[17] Commenter 4 on, "Covid-19 ierobežošanai no 9. novembra izsludina ārkārtējo situāciju; stingri ierobežojumi (plkst. 21:15) [For containment of Covid-19, an emergency declared from 9 November; strict restrictions (at 21:15)]," 6 November 2020. [Online]. Available:

https://www.delfi.lv/news/national/politics/covid-19ierobezosanai-no-9-novembra-izsludina-arkartejo-situacijustingri-ierobezojumi-plkst-2115.d?id=52637311 